The moderating role of demographic characteristics between green ...

Dr. Sherif Taher Mohammed \& Dr. Reem Mohamed Shafie

\title{
The moderating role of demographic characteristics between green marketing mix of eco-friendly products and customer switching behaviour: a case of the Egyptian automobile market
}

\author{
By \\ Dr. Sherif Taher Mohammed \\ Sadat Academy for Management Sciences \\ Dr. Reem Mohamed Shafie \\ Sadat Academy for Management Sciences
}

\section{Abstract:}

Purpose - There is an escalating need for further studies to comprehend the consumer's change in behaviour towards ecofriendly automotive products for its growing trend in the emerging markets. Introducing environmentally friendly cars is, therefore one of the industrial measures to resolve this challenge by enabling at minimum, some proportionate decrease in world gas-emissions. So, governments and global vehicle manufacturers are dedicated to shifting Egyptian consumer behaviour in the vehicle sector, to search for ways to boost green cars' usage, causing a major growth in the global market of electric vehicles. That required to investigate the factors influencing Egypt's green vehicle purchasing intent. The green marketing mix is a tactic used by several businesses in varied industries to promote purchasing of green goods. A variety of researches have examined the green marketing mix strategies and its relationship with customer behaviour. In the present situation, customers are searching for well-known premium products that 
The moderating role of demographic characteristics between green ...

Dr. Sherif Taher Mohammed \& Dr. Reem Mohamed Shafie

suit their needs. Though, people respect the environment and believe in preserving it, and are mindful of the environmental issues, their purchase is not necessarily relying on that base. Given this, the purpose of the study is to focus on the green marketing mix variables that influence the Egyptian customers' green purchasing behaviour, when buying automotive products.

More precisely, the purpose of this study is to explore the impact of the green marketing mix on customer switching behaviour towards eco-friendly cars. Also, the moderating effect of demographic variables has been applied to the framework model.

Design/methodology/approach - the research design is both qualitative and quantitative, where two data types were used: Secondary Data and Primary Data. For a theoretic overview, secondary data were gathered from numerous blogs and academic articles concerned with topics connected to the research question. The primary data required to meet the study goals were obtained using the E-Questionnaire tool presented by Google forms for applying the questionnaire via the Internet and filling it out by various respondents. A sum of 305 eligible responses has been received. Hypotheses were evaluated by the Route Analysis Approach using the Amos Ver.18 software. The research utilized one of the regression tools, the Structural Equations Modelling (SEM) technique in the Route Analysis software, using the Maximum Likelihood 
The moderating role of demographic characteristics between green ...

Dr. Sherif Taher Mohammed \& Dr. Reem Mohamed Shafie

Estimates (MLE) approach in the AMOS program. Thus, the moderating role of demographic variables on the interaction between the green marketing mix strategies and consumer switching behaviour toward eco-friendly cars could be tested.

Findings - The findings showed that green marketing mix had a substantial positive effect on the consumer's switching behaviour towards eco-friendly automotive products. Moreover, it has been observed that different genders, ages, levels of education, and marital statuses of Egyptian consumers affected their attitude regarding eco-friendly automobile products, while the level of income did not influence it.

Originality/value - The research aims at filling the substantial gap regarding Egyptian consumers buying behaviour for green automotive products. This paper remains one of the few research projects designed to resolve numerous green marketing mix issues that affect buying behaviour for eco-friendly automotive products in developing countries, like Egypt. It will, however, serve as a guide for eco-friendly automobile manufacturing firms to consider the green marketing mix variables that may affect consumer attitudes towards eco-friendly vehicles in related contexts. Results suggest a need for policymakers and practitioners to introduce effective strategies for encouraging the population to adopt green vehicles, thus increasing the acceptance rate of pro-environmental automobiles. Besides, this study has used the power of the Path Analysis technique and the 
The moderating role of demographic characteristics between green ...

Dr. Sherif Taher Mohammed \& Dr. Reem Mohamed Shafie

SEM method applied by the Amos software to deal with higherorder structures, enabling us to create and validate a suitable methodology that would be valuable for practitioners.

Keywords - Green Marketing Mix, Green Product, Green Place, Green Promotion, Eco-friendly automobile products, Customer Switching Behaviour.

Paper Type: Research paper

\section{1- Introduction:}

Purchasing of green goods is growing amongst customers and organizations. Also, vehicle manufacturing companies around the world employ optimized, safe, and clean technologies and methods, when manufacturing cars to minimize the harm on human beings and the environment (Karurkar, S et al., 2018; Singhal, N., \& Effiong, J, 2016). Thus, Green marketing has a positive effect on health and the environment. It also promotes coordinated purity efforts in both production and consumption. At the same time, people are conscious of natural products and pure means of products' manufacturing, consuming, and discarding. (M.D., P., \& Akhil, A.2017). On one hand, green cars, have low toxic emissions and are fuel-efficient, with four different types of environmental vehicles available on the market, involving hybrid vehicles, hydrogen vehicles, electric vehicles, and solar vehicles (Joshi \& Rao, 2013). On contrary, conventional vehicles release poisonous emissions that are harmful to health (Razak, Ahmad, Bujang, Talib, \& Ibrahim,

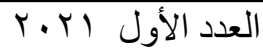

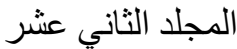


The moderating role of demographic characteristics between green ...

Dr. Sherif Taher Mohammed \& Dr. Reem Mohamed Shafie

2013). To improve purchases that would sequentially stimulate green vehicles' production, we ought to get a deeper insight into consumers' shifting attitudes toward green vehicles, along with identifying the variables that affect green car preference. That would allow manufacturers to produce eco-friendly cars of choice, and consequently, increase the consumer's readiness to buy green cars (Beyzavi \& Lotfizadeh, 2014). While a variety of studies have been conducted on environmental behaviours, environmental awareness, previous practice, social effect, environmental labeling, and incentives, empirical research is lacking regarding the effect of the green marketing strategy on Egyptian customer behaviour in an automotive sense. Also, this research may help policymakers develop initiatives that affect behaviours and purchasing attitude to avoid more air pollution and reduce $\mathrm{CO}_{2}$ emissions from the transport industry, since 'Going Green' appears to be a chain of moves toward a cleaner environment (Gazzola, P et al., 2019). Despite its significance, a major issue regarding green marketing is exerting little effort to academically researching it. The concept of eco-friendly marketing is how the customers are keen to spend more to preserve a healthier atmosphere. Therefore, it needs to be intelligently and appealingly promoted to rationalize the extra cost. For that purpose, each organization has a certain chosen marketing combination. Some of them have four themes to which they stick, whereas others use seven themes in their marketing

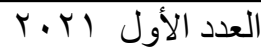

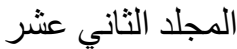


The moderating role of demographic characteristics between green ...

Dr. Sherif Taher Mohammed \& Dr. Reem Mohamed Shafie

mix. The four themes (4P's) of green marketing mimic those of conventional marketing that are: product, place, price, and promotion. Added to those four themes are another three themes forming the 7 P's that involve: packaging, people, and positioning (Mahmoud, 2018). Additionally, recent research primarily concentrated on green marketing tactics (Devi Juwaheer et al., 2012; Awan, 2011; Fan and Zeng, 2011; Solvalier, 2010). Besides, several studies investigated the association between green goods and consumer purchase intention (Laroche et al., 2001; Paul and Rana, 2012; Lam and Mukherjee, 2005; Gan et al., 2008). However, limited studies have assessed the green marketing mix and the intention to purchase. For instance, Ansar (2013) examined the green marketing mix as eco-friendly advertisement, environmental price, and green packaging. On the other side, Wanninayake and Randiwela (2008) have investigated green place, green product, green promotion, and green package. It was claimed by Schiffman et al. (2008) that customer's behaviour is the core of the promotional theory. Thus, the idea of customer behaviour shifting in the automotive sector has been addressed herein, as it can be of great significance to eco-friendly vehicle perspective providers to recognize the motives why customers show changing attitude. Therefore, firms can obtain an insight into customer's expectations and preferences as well as the means

of fulfilling their needs by implementing successful green marketing mix tactics to 
The moderating role of demographic characteristics between green ...

Dr. Sherif Taher Mohammed \& Dr. Reem Mohamed Shafie

shift Egyptian customers to have green behaviour. Green customer is truly serious about the environment and, thus, buys utilities or goods that are ecologically friendly. Finally, in terms of the global and local trend of the expansion in usage of clean energy (from which, electric energy is considered as one of the most important types), the encouragement of eco-friendly products (automobiles on top of them, due to their great effect in lowering pollution rates) have placed the automobiles' manufacturing factories into a great challenge to influence the consumer's thoughts into the usage of eco-friendly automobiles. Hence the research problem presents in the reconnaissance of the role of marketing mix's elements in supporting the change of the Egyptian consumer behaviour into the usage of eco-friendly automobiles, influenced by the demographic characteristics as a moderated variable, as they were not researched before.

\section{2-Literature Review:}

\subsection{Green marketing mix:}

Marketing mix is a collection of adjustable variables that corporations should implement to affect the behaviour of the purchasers (Kotler \& Armstrong, 2009). So, like the conventional marketing mix, green marketing also, has four aspects: green price, green product, green place (distribution), and green promotion. Processes related to both are the same, but the principles are distinct. Green 
The moderating role of demographic characteristics between green ...

Dr. Sherif Taher Mohammed \& Dr. Reem Mohamed Shafie

marketing mix approaches are eco-friendlier. Green marketing, classified as ecologically sustainable marketing, implies the organization's attempts to design, price, promote and distribute goods that would not harm the ecosystem (Parlan, et al.,2016).

\subsubsection{Green Product:}

The product represents the core of the environmental target market and the keystone of the green marketing approach. Green commodity aims to protect and enhance the natural environment together with maintaining power and resources as well as minimizing or eliminating the use of hazardous chemicals, emissions, and waste products (Ottman et al., 2006). Green products are described as products made by nontoxic materials, using ecologically sustainable approaches, and are accredited by a recognized organization (Kumar and Ghodeswar, 2015). Also, greens products, are interchangeably called eco-friendly (Kawitkar, 2013), environmental-friendly, and ecological (Chen \& Chai, 2010). According to Chen and Chai (2010), the environmental product has a low negative environmental impact, and it integrates techniques for recycled products, minimized packaging, and utilizing fewer toxic substances. Green goods are designed to reduce emissions and waste, save resources and the environment. In general, green products are those doing minimal damage to the natural 
The moderating role of demographic characteristics between green ...

Dr. Sherif Taher Mohammed \& Dr. Reem Mohamed Shafie

environment (Dahl \&Persson, 2008), as they utilize natural energy for production (Sivesan, et al. 2013).

Many customers are aware of green goods. That knowledge of green goods is crucial to driving purchase decisions. Also, researchers have revealed that green goods are a major consideration that significantly affects customers' purchase decisions (Siddique \& Hossain, 2018). Such green goods (e.g., electrical vehicles, recycled goods, organic tea, energy economical electronics, etc.) are ecologically safe, desirable, and substantially superior versions in terms of their production, use, and disposal, compared to conventional retail options available on the market (Aman et al., 2012).

\subsubsection{Green Price:}

Price is among the most fundamental and customer-sensitive aspects of the marketing mix. Most customers would only be willing to pay a premium price when they expect added product benefits (Eric, 2007). Price represents a crucial component that, if it is well handled, can generate a perfect combination of revenues and returns, contrary to other marketing elements that can make costs (Awan, 2011). Furthermore, customers are more likely to purchase a green item with environmental packaging, considering that they agree with the cost-benefit study. As ecologically aware customers are ready to pay premiums for these goods (Tsarenko, Y., et al, 2013), therefore, companies need to provide market 
The moderating role of demographic characteristics between green ...

Dr. Sherif Taher Mohammed \& Dr. Reem Mohamed Shafie

awareness regarding those green goods, and prove their commitment to environmental protection, so that customers can appreciate the demand on green products (Marchi \& Zanoni, 2017). As stated by Hashem and Al-Rifai (2011), environmental pricing describes the cost in the context of the firm's regulations, concerning environmental interests inflicted by the laws and organization's directives or programs in this respect.

Green pricing considers individuals, planet, and revenue through an approach that cares about the wellbeing of workers and the public and guarantees effective productivity. Added value can be obtained by altering its emergence, compatibility, and personalization, to name a few. (Shil, 2012). According to Hossain and Khan (2018), green price is the cost related to ecologically focused goods. Because of their environmentally sustainable properties, these goods can be marketed at a premium cost than regular products. Green prices ought to be fair and feasible (Soonthonsmai \& Vuttichat, 2007). Besides, environmentally friendly products may be found to be cheaper, when considering the cost of the production process (Kumar, p., 2015).

\subsubsection{Green place (distribution):}

The distribution network is the reinforced ties between the firm and customers. It also decides the time and place to manufacture a product that would have a major effect on the consumer attraction (i.e., the option of when and where the product is 
The moderating role of demographic characteristics between green ...

Dr. Sherif Taher Mohammed \& Dr. Reem Mohamed Shafie

available has a substantial influence on the attracted customers (Garg \& Sharma,2017). The Green market distribution network, known as the "Green Place", comprises distribution gates, which enable the distribution and ensure conducting protocols under environmental standards and specifications (Hashem and AlRifai, 2011), using environmentally safe products and by providing recycling infrastructure at the firm's premise (Achola and Were, 2018). The environmental place is concerned with handling infrastructure to reduce transport pollution, thus ultimately help reduce the carbon footprint (Shil, 2012). On the other hand, the distribution does not essentially have to be a costrelevant, since there are many benefits to a location that can produce such profits and outcomes. This aspect of the marketing mix is dealt with by the method of interacting with distance (Awan, 2011). For green ventures to be founded and to become cost-effective, companies must ensure that their retailers are concerned about the environment and implement a green distribution policy (Eric, 2007).

Green distribution is a quite sensitive process, where consumers must be assured of the 'environmental aspect' of the service. The green world is a steadily controlled environment; therefore, a high degree of adherence is critical to the distribution of green goods (Yazdanifard and Mercy, 2011). Little concerned consumers are going out of their way to purchase green goods (Singh, 2013).

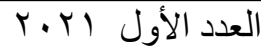

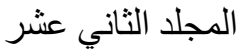


The moderating role of demographic characteristics between green ...

Dr. Sherif Taher Mohammed \& Dr. Reem Mohamed Shafie

\subsubsection{Green promotion:}

Green promotion and advertisement imply conveying actual environmental knowledge to customers, who are having a connection with the company's operations. So, several companies adopt environmental debates for their advertising campaigns (Shil, 2012). There is a great deal of concern among customers about environmental advertising. This is typically achieved by stressing the representation of corporate promotional slogans and often by collaboration and association with environmental or social organizations (Wong \&Stoneman, 2009). This aspect of the green marketing mix covers a variety of operations, such as paid advertisements, direct marketing, public relations, sales promotions and social media ads as well as promotional activities (Fan \& Zeng, 2011). Environmental advertising as commercial messaging is an efficient marketing tactic that could be used to satisfy the need of biologically concerned consumers (Ankit \& Mayur,2013).

Green promotion corresponds to conveying actual environmental knowledge to customers who are participating in the company's operations. Additionally, the commitment of companies to maintain natural properties is meant to fascinate the potential customers (Shirsavar \& Fashkhamy, 2013). It is also the intention of companies to conserve resources to attract the target market

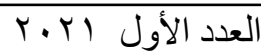

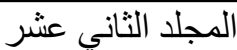


The moderating role of demographic characteristics between green ...

Dr. Sherif Taher Mohammed \& Dr. Reem Mohamed Shafie

(Phau\&Ong, 2007). Moreover, credibility is the secret to communication in green marketing.

\subsection{Consumer switching behaviour:}

The interpretation of customer attitude or "Knowing/understanding consumers" is not as straightforward as it appears to be. However, it is critical for marketers to quite subjectively study and analyze their customer demands to recognize their expectations, preferences, perceptions, and, ultimately, their behaviours while purchasing (Kotler P., 2012). As claimed by Balaji, M. S. (2015), customer behaviour is a process of decision-making and physical interaction of individuals involved in the evaluation, purchase, usage, or disposal of products and services. Likewise, customer behaviour is described as the entirety of customer decisions regarding the purchase, use, and disposal of products, services, events, interactions, individuals, and ideas through decision-making across time (Aarikka-Stenroos \& Jaakkola, 2012).

Consumer switching behaviour emerges as they disregard their current product supplier for another supplier's product, with the initial supplier having lost potential income and being required to pay for attracting new consumers (Keaveney, 1995). Thus, this study aims to expand the awareness of the marketing mix strategies that affect the shifting of Egyptian customers to buy eco-friendly vehicles. With acknowledging the serious 
The moderating role of demographic characteristics between green ...

Dr. Sherif Taher Mohammed \& Dr. Reem Mohamed Shafie

environmental challenges, possibly resulting from the unsustainable use of power and non-renewable environmental assets, the abundant food and goods' supplies, nonenvironmental manufacturing practices as well as environmental hazards, a growing number of people are environmentally aware, fearing the scarceness of natural resources and the fragility of the environment. Such environmental consciousness helps people take a constructive view of eco-friendly practices and inspires them to participate more often in green actions in their daily lives (Han \& Hsu, 2011). The rationale for that switching is linked to the different types of shifting defined as absolute, internal, or partial as per a specific trend of consumer preferences, with conduct being the reference point (Edvardsson, Gustafsson, and Roos 2002a).

Customers who consider the environmental effects of their spending habits and who are keen on changing their buying attitudes are considered ecologically friendly customers (Ritter et al., 2015). Green customers are those with environmental interests, who have an incentive to consider environmental issues while making purchasing choices and who transform their attitude into environmental one (Rahman, 2013). Eventually, the present findings indicate that customers' purchasing decisions appear to be affected by the practices of the marketing mix. Hence, the automotive industry marketers need to maintain marketing strategies to raise awareness of greening. Marketers will need to produce more exhibits, samples, promotions, and 
The moderating role of demographic characteristics between green ...

Dr. Sherif Taher Mohammed \& Dr. Reem Mohamed Shafie

delivery to offer greening information and raise the green purchasing intention of Egyptian customers.

According to the previous studies, the moderating role of demographic characteristics between green marketing mix of eco-friendly products and customer switching behaviour unexplored in the academic literature, and there are no studies found the relationship between the current study variables. Therefore, as shown in figure (1) hypothesis was developed in line with the objectives of the research as follows:

H1: There is a positive relationship between Green marketing mix (green price, green product, green promotion, and green place), and Customer switching behaviour.

H2: Green marketing mix (green price, green product, green promotion, and green place) positively affects customer switching behaviour moderated by the effect of demographic characteristics.

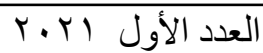

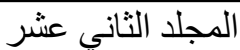


The moderating role of demographic characteristics between green ...

Dr. Sherif Taher Mohammed \& Dr. Reem Mohamed Shafie

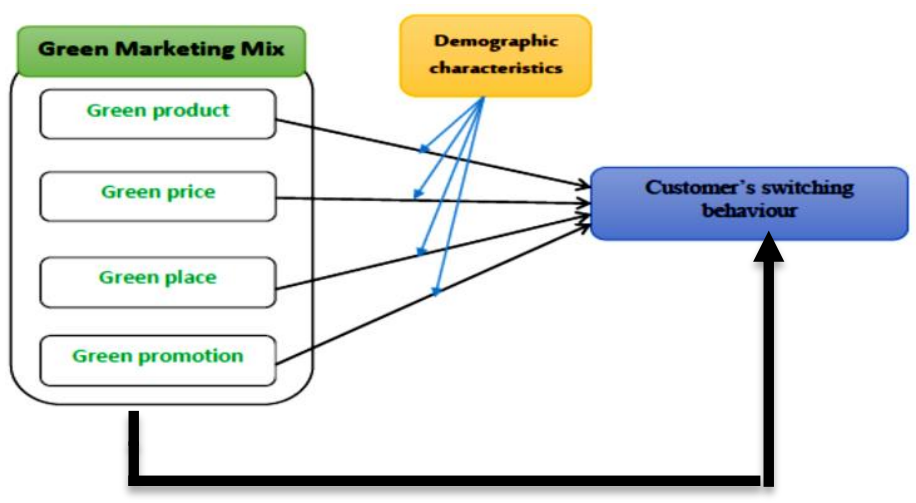

Figure 1

\section{Conceptual diagram explaining the Research Model.}

\section{3- Research Methodology:}

The current study relies on the empirical descriptive methodology that involves the process of surveying the database by reference to former research, for constructing a theoretical basis for the conducted study, using certain qualitative research approaches along with the field survey scheme for collecting data by applying a targeted survey.

\section{1: Data Collection and Sampling}

In this research, the survey questionnaire approach was utilized for collecting primary data. The present analysis employed probability sampling, primarily a basic random sampling technique that has the advantage of allowing for theoretical generalization of the results. 
The moderating role of demographic characteristics between green ...

Dr. Sherif Taher Mohammed \& Dr. Reem Mohamed Shafie

Owing to the customer population's large size, the time factor, and cost considerations, which act as restraints in research, the sampling approach was chosen for gathering data needed for the consumer field analysis. The sample size was estimated as 384 individuals, as per the act of large numbers.

A five-point Likert - type scale ranged from strongly disagreed (1) to strongly agreed (5) was applied to evaluate each attitude element and data collection was obtained using the E-Questioner Tool presented by Google models for applying the questionnaire through the internet. We collected 390 responses, 305 which are retained for analysis. Data collection lasted approximately (10) months from Oct.2019 to Aug.2020. Data analysis used SPSS and Amos Ver.18 statistical software packages.

\section{3-2: Measures}

To ensure that the measures used in the present study have a high degree of reliability, it was based on Cronbach's alpha as the most significant reliability analysis methods in evaluating the degree of internal consistency between the contents of the measures. In addition, it is used to determine the extent to which the scale items represent the target variable and not another (Tavakol \& Reg 2011).

To develop the measurement of involved variables and number of items, some previous studies are considered as shown as table (1). The study involved two kinds of variables, the green

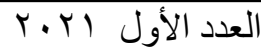

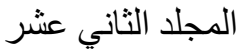


The moderating role of demographic characteristics between green ...

Dr. Sherif Taher Mohammed \& Dr. Reem Mohamed Shafie

marketing mix (the independent variable) and the consumer switching behaviour toward eco-friendly cars (the dependent variable). The items and questions employed were constructed and optimized based on the literature, while the responses were calculated on a Likert scale of five points. Green marketing mix was measured using four adapted sub-variables: Green place, Green promotion, Green price, and Green product. The scale consists of eighteen items which measure the four dimensions or facets of the construct, while consumer switching behaviour was captured by six items. Finally, six items were used to measure the moderating variable which is customers' demographic variables. Certain closed questions were used to assess the sample's demographics.

Table 1. The measures are used in the study

\begin{tabular}{|c|c|l|}
\hline Variable & Number of items & \multicolumn{1}{|c|}{ Reference } \\
\hline Green Marketing Mix & 18 & $\begin{array}{l}\text { (parlan,et al,2016) (Siddique \& Hossain, } \\
\text { 2018) (Achola and Were, 2018) }\end{array}$ \\
\hline $\begin{array}{c}\text { Customer switching } \\
\text { behaviour }\end{array}$ & 6 & $\begin{array}{l}\text { (Keaveney, 1995) (Aarikka-Stenroos \& } \\
\text { Jaakkola, 2012) }\end{array}$ \\
\hline
\end{tabular}

After the data was gathered and retrieved from the survey program, the data was entered into the SPSS. then, the data was cleaned up by deleting incorrect answers, defective questionnaires, or modifying data in case of misinterpretations or lack of regard. The fields were left empty for missed entries. 
The moderating role of demographic characteristics between green ...

Dr. Sherif Taher Mohammed \& Dr. Reem Mohamed Shafie

\section{3-2-1: Reliability of Measures Used in the Field Study}

To ensure the scale's validity, two steps were taken; firstly, the questionnaire was presented to a group of experts and specialists in the field of marketing and their observations were considered. Furthermore, the second step in the evaluation of predictive measures is validity evaluation. Validity is looked at by considering the convergent validity and distinguishing validity of a construct. The coefficient Alpha methodology is known to be one of the most important techniques used in the calculation of reliability measurements. It achieves a high level of precision when calculating the degree of conformity of the various measurements used. Help for convergent validity is given when each element has outer loads above 0.70 and the Average Variance Derived (AVE) of each construct is 0.50 or greater. The AVE is the great mean value of a group of indicators 'squared loadings (Hair et al., 2014) and is analogous to a construct's communality. Put succinctly, an AVE of 0.50 indicates more than half the variance of its indicators are clarified by the building.

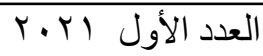

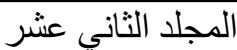


The moderating role of demographic characteristics between green ...

Dr. Sherif Taher Mohammed \& Dr. Reem Mohamed Shafie

Table (2): Constructs and findings of confirmatory factor analyses: descriptive statistics, reliability, convergent validity, and discriminant validity

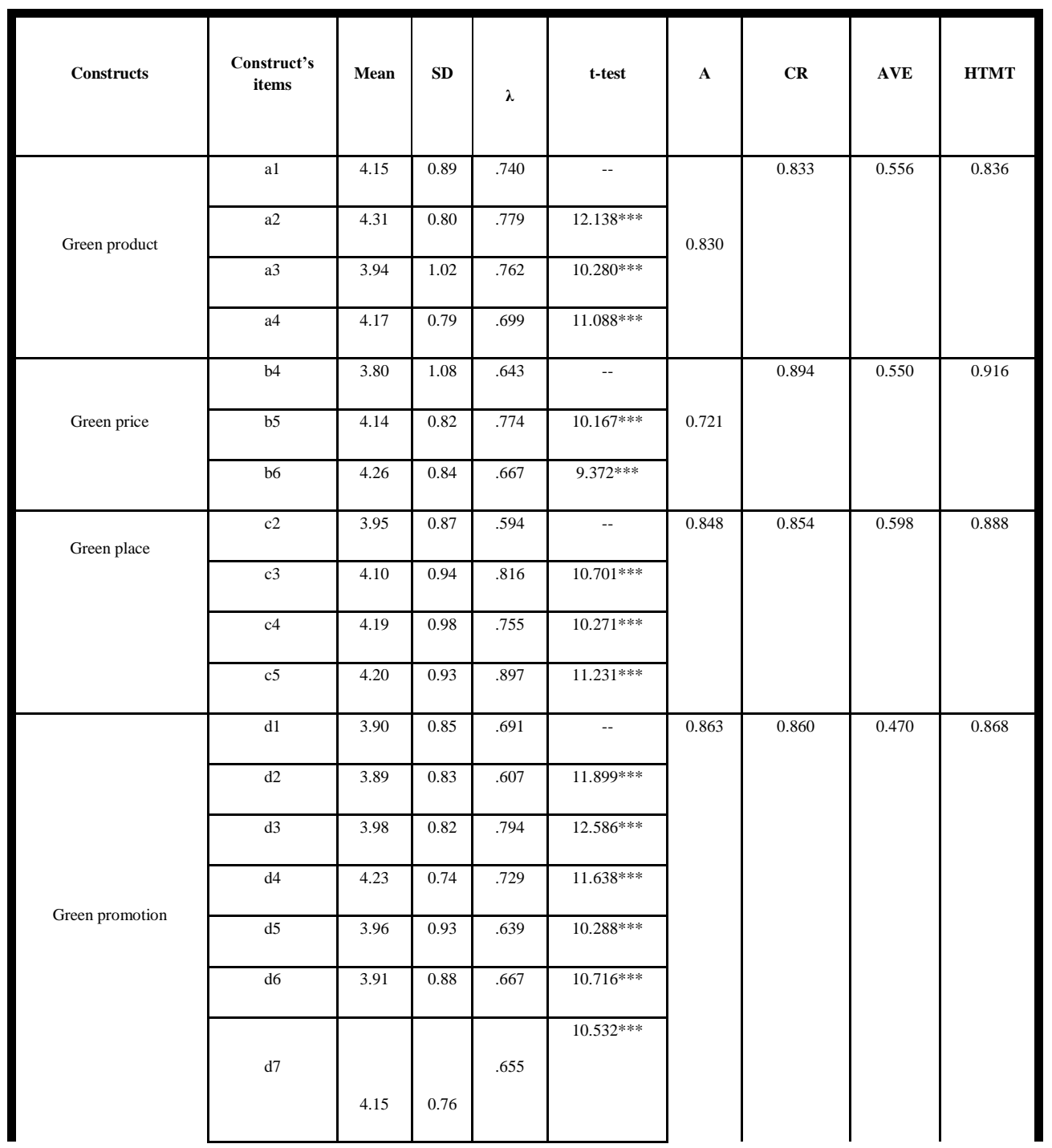

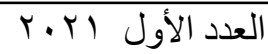


The moderating role of demographic characteristics between green ...

Dr. Sherif Taher Mohammed \& Dr. Reem Mohamed Shafie

\begin{tabular}{|c|c|c|c|c|c|c|c|c|c|}
\hline \multirow{6}{*}{$\begin{array}{l}\text { Customer's switching } \\
\text { behaviour }\end{array}$} & e1 & 3.56 & 0.97 & .626 & -- & \multirow[t]{6}{*}{0.864} & \multirow[t]{6}{*}{0.869} & \multirow[t]{6}{*}{0.531} & \multirow[t]{6}{*}{0.889} \\
\hline & e4 & 3.97 & 0.77 & .706 & $10.192 * * *$ & & & & \\
\hline & e5 & 3.92 & 0.92 & 817 & $11.317 * * *$ & & & & \\
\hline & e6 & 3.85 & 0.89 & .843 & $11.550^{* * * *}$ & & & & \\
\hline & e7 & 3.96 & 0.88 & .763 & $10.796^{* * * * *}$ & & & & \\
\hline & e9 & 3.67 & 0.84 & .579 & $8.705 * * *$ & & & & \\
\hline
\end{tabular}

*** Significant at a level less than (0.001). $\alpha$ :Cronbach's alpha.

CR: composite reliability. AVE: average variance extracted. HTMT: Heterotrait-monotrait ratio

According to Table (2), the researcher can conclude the following:

1. All standardized regression weights (factor loading) are greater than 0.50 , which means that all measured variables are statistically significant at a level less than (0.001), i.e., the measured variables represent the constructs, i.e., this shows that there exist some common points of convergence (Hair et al., 2014).

2. The $\mathrm{CR}$ shows results that are greater than 0.70 which means that the variables did converge at some point (Hair et al., 2014).

3. As a result of Squared Multiple Correlations; the average variance extracted for all latent constructs is (0.541), after excluding the variables (a5), (b1_3), (c1), and (e2_3),(e8) from the constructs of Green product, Green price, Green place, Customer's switching behavior, respectively., This

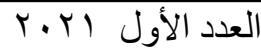

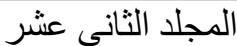


The moderating role of demographic characteristics between green ...

Dr. Sherif Taher Mohammed \& Dr. Reem Mohamed Shafie

shows that the latent variables had a high convergent validity (Fornell \& Larchker, 1981; Hair et al., 2014).

4. AVEs of all scales turned out to be greater than the cut-off values (0.50), (Fornell \& Larchker, 1981; Hair et al., 2014).

5. Lately, the solution to estimate discriminant validity has been stated as Heterotrait-monotrait (HTMT) correlations' ratio. HTMT represents averaged correlations of the heterotraitheteromethod, compared to the averaged correlations of the monotrait-hetero-method. If the HTMT 's value is greater than that threshold, there is a loss of discriminant validity (Henseler, Ringle \& Sarstedt, 2015). Some of the authors propose (0.85) as a threshold point (Kline, 2011), while others suggest (0.90) as the threshold point (Teo et al., 2008). As indicated by Table (1), the HTMT ratio is lower than (0.90), but not for the green price construct that is close to a cut-off value of (0.90), meaning that the latent variables have large discriminant validity.

6. All the goodness of fit measures of the model showed a significant fit of the results i.e., all indicators at acceptable limits or identical to cut-off values, GFI, AGFI, NFI, RFI, IFI, TLI, and CFI approximately close to the threshold value (0.90) and Normed Chi-Square with cut-off values less than (5), then the researcher can conclude that the possibility of matching the actual form to the model estimated.

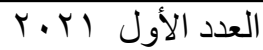
المجلد الثاني عشر 
The moderating role of demographic characteristics between green ...

Dr. Sherif Taher Mohammed \& Dr. Reem Mohamed Shafie

7. The values of Root Mean Square Residual (RMR) and Root Mean Square Residual Approximation (RMSEA) approximately less than (0.08), which indicates a close fit of the model concerning the degrees of freedom.

8. Overall, the evidence of a good model fit, reliability, convergent validity, and discriminant validity indicates that the measurement model was appropriate for testing the measure the effect of the moderating role of demographic characteristics on the relationships between marketing mix of green products and customer switching behaviour: a case of the Egyptian automobile market.

\section{3-2-2: Data analysis and hypothesis testing:}

The following is an analysis of the study data and discuss the results and hypothesis testing, as follows:

H1: there is a positive relationship between Green marketing mix (green product, green price, green place, and green promotion), and Customer switching behaviour

Table (3): Pearson correlation matrix to measure a significant linear relationship between the constructs of Green Marketing Mix, and customer switching behaviour

\begin{tabular}{|c|c|c|c|c|c|}
\hline Constructs & $\begin{array}{c}\text { Green } \\
\text { product }\end{array}$ & Green price & Green place & $\begin{array}{c}\text { Green } \\
\text { promotion }\end{array}$ & $\begin{array}{c}\text { Customer's } \\
\text { switching } \\
\text { behaviour }\end{array}$ \\
\hline Green product & 1 & & & & \\
\hline Green price & $* * * 0.516$ & 1 & & & \\
\hline
\end{tabular}

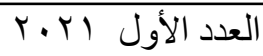
المجلد الثاني عشر 
The moderating role of demographic characteristics between green ...

Dr. Sherif Taher Mohammed \& Dr. Reem Mohamed Shafie

\begin{tabular}{|c|c|c|c|c|c|}
\hline Constructs & $\begin{array}{c}\text { Green } \\
\text { product }\end{array}$ & Green price & Green place & $\begin{array}{c}\text { Green } \\
\text { promotion }\end{array}$ & $\begin{array}{c}\text { Customer's } \\
\text { switching } \\
\text { behaviour }\end{array}$ \\
\hline Green place & $* * * 0.557$ & $* * * 0.464$ & 1 & 1 & \\
\hline $\begin{array}{c}\text { Green } \\
\text { promotion }\end{array}$ & $* * * 0.619$ & $* * * 0.500$ & $* * * 0.644$ & 1 \\
\hline $\begin{array}{c}\text { Customer's } \\
\text { switching } \\
\text { behaviour }\end{array}$ & $* * * 0.654$ & $* * * 0.583$ & $* * * 0.636$ & $* * * 0.676$ & 1 \\
\hline
\end{tabular}

*** Significant at a level less than (0.001).

\section{From table (3), the researcher revealed that:}

1. There are significant positive linear relationships between the constructs of Green Marketing Mix in terms of Green product, Green price, Green place, Green promotion, and the construct of Customer's switching behaviour, at Significant at a level less than (0.001).

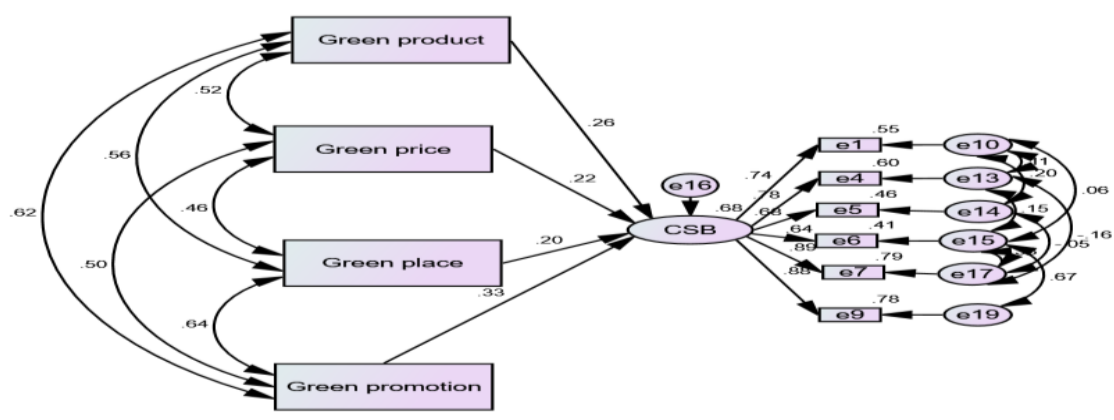

Figure (2): structural equation modeling for testing the effect of the constructs of Green Marketing Mix on the construct of Customer's

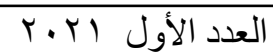$$
\text { المجلد الثاني عشر }
$$ 
The moderating role of demographic characteristics between green ...

Dr. Sherif Taher Mohammed \& Dr. Reem Mohamed Shafie

Table (4): Regression weights according to Maximum Likelihood Estimates for testing the effect of the constructs of Green arketing Mix on the construct of Customer's switching behaviour

\begin{tabular}{|c|c|c|c|c|c|c|}
\hline \multicolumn{3}{|c|}{ Path } & Standardized & S.E. & C.R. & SIG. \\
\hline CSB & $<--$ & Green price & .220 & .025 & 4.736 & $0.001 * * *$ \\
\hline CSB & $<--$ & Green place & .201 & .034 & 3.904 & $0.001 * * *$ \\
\hline CSB & $<--$ & $\begin{array}{c}\text { Green } \\
\text { promotion }\end{array}$ & .326 & .037 & 5.802 & $0.001 * * *$ \\
\hline CSB & $<---$ & $\begin{array}{l}\text { Green } \\
\text { product }\end{array}$ & .259 & .033 & 4.983 & $0.001 * * *$ \\
\hline e1 & $<---$ & CSB & .740 & & & \\
\hline e4 & $<--$ & CSB & .776 & .074 & 14.171 & $0.001 * * *$ \\
\hline e5 & & CSB & .678 & .077 & 12.929 & $0.001 * * *$ \\
\hline e6 & & CSB & .639 & .119 & 10.813 & $0.001 * * *$ \\
\hline e7 & & CSB & .889 & .094 & 15.474 & $0.001 * * *$ \\
\hline e9 & & CSB & .881 & .090 & 15.476 & $0.001 * * *$ \\
\hline
\end{tabular}

Normed Chi-Square=3.133RMR=0.027 GFI=0.960 AGFI=0.894 NFI=0.969 RFI=0.934 IFI=0.979 TLI=0.954 $\mathrm{CFI}=0.979$ RMSEA $=0.084$

*** Significant at a level less than (0.001).

\section{From table (4), the researcher revealed that:}

1. There is a significant positive effect of the constructs of Green Marketing Mix in terms of Green product, Green price, Green place, and Green promotion on the construct of Customer's switching behaviour, at a significant level less than (0.001). This validates the first research hypothesis; there is a positive significant effect of the constructs of Green Marketing Mix on the construct of 
The moderating role of demographic characteristics between green ...

Dr. Sherif Taher Mohammed \& Dr. Reem Mohamed Shafie

customer switching behaviour, with regression model as the following:

CBS $=0.259 *$ Green product $+0.220 *$ Green price $+0.201 *$ Green place+0.326* Green promotion

The exogenous variables were accepted, Green price, Green place, and Green promotion, in SEM explain (68\%) from the total variation of the dependent variable; Customer's switching behaviour, the rest percent due to either the random error in the regression model or other Independent Variables excluded from the regression model.

2. All the goodness of fit measures of the model indicates that all indicators at acceptable limits or greater than cutoff values, especially GFI, AGFI, NFI, RFI, IFI.TLI, and CFI close to one and Normed Chi-Square with a cut-off value less than (5). The fit measures indicate the goodness of fit of the structural model and its ability to measure the effectiveness of the constructs of Green Marketing Mix on the construct of customer' switching behaviour.

3. Both Root Mean Square Residual (RMR) and Root Mean Square Residual Approximation (RMSEA) less than (0.08), which indicates a close fit of the theoretical model to the actual model.

H2: Green marketing mix (green product, green price, green place, and green promotion) positively affects customer 
The moderating role of demographic characteristics between green ...

Dr. Sherif Taher Mohammed \& Dr. Reem Mohamed Shafie

\section{switching behaviour moderated by the effect of demographic characteristics.}

Table (5): Multiple Linear Regression Model to determine the effect of the demographic characteristics in terms of gender on the relationship between marketing mix and customer switching behaviour

\begin{tabular}{|c|c|c|c|c|c|}
\hline Variable & Coefficient & t-Statistic & Prob. & LLCI & ULCI \\
\hline \multicolumn{6}{|c|}{ 1-the effect of the construct of Green product on customer switching behavior } \\
\hline Constant & 2.7208 & 8.7588 & $0.001 * * *$ & 2.1095 & 3.3321 \\
\hline Green product & .2627 & 3.5501 & $0.001 * * *$ & .1171 & .4083 \\
\hline GENDER & -.9715 & -2.2646 & $0.0243 *$ & 1.8157 & -.1273 \\
\hline Green product* GENDER & .2410 & 2.3596 & $0.0189 *$ & .0400 & .4421 \\
\hline \multicolumn{6}{|c|}{$\mathrm{R}^{2}=17.56 \%$ F-test $=21.3$ sig $=0.001 * * *$ RMSE $=0.3843$} \\
\hline \multicolumn{6}{|c|}{ 2-the effect of the construct of Green price on customer switching behavior } \\
\hline Constant & 2.2651 & 6.8034 & $0.001 * * *$ & 1.6099 & 2.9203 \\
\hline Green price & .3759 & 4.6953 & $0.001 * * *$ & .2184 & .5335 \\
\hline GENDER & .4878 & 1.1441 & .2535 & -.3512 & 1.3267 \\
\hline Green price * GENDER & -.1070 & -1.0384 & .2999 & -.3098 & .0958 \\
\hline \multicolumn{6}{|c|}{$\mathrm{R}^{2}=11.6 \%$ F-test13.1 sig=0.001*** $\mathrm{RMSE}=.4121$} \\
\hline \multicolumn{6}{|c|}{ 3-the effect of the construct of Green place on customer switching behavior } \\
\hline Constant & 2.2926 & 7.9260 & $0.001 * * *$ & 1.7234 & 2.8619 \\
\hline Green place & .3660 & 5.3223 & $0.001 * * *$ & .2306 & .5013 \\
\hline GENDER & -.1025 & -.2659 & .7905 & -.8607 & .6558 \\
\hline Green place * GENDER & .0375 & .4075 & 6839 & -.1437 & .2187 \\
\hline \multicolumn{6}{|c|}{$\mathrm{R}^{2}=19.3 \%$ F-test $=23.9$ sig=0.001*** $\mathrm{RMSE}=.3761$} \\
\hline \multicolumn{6}{|c|}{ 4-the effect of the construct of Green promotion on customer switching behavior } \\
\hline Constant & 1.7398 & 5.8608 & $0.001 * * *$ & 1.1556 & 2.3239 \\
\hline Green promotion & .5190 & 7.0469 & $0.001 * * *$ & .3741 & .6639 \\
\hline GENDER & -1.1318 & -2.7884 & $0.0056 * *$ & -1.9306 & -.3330 \\
\hline Green promotion * GENDER & .2841 & 2.8337 & $0.0049 * *$ & .0868 & .4815 \\
\hline
\end{tabular}

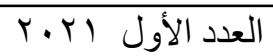


The moderating role of demographic characteristics between green ...

Dr. Sherif Taher Mohammed \& Dr. Reem Mohamed Shafie

According to the Multiple Regression model using ordinary least squares, it can be concluded that:

\section{1- The coefficient of determination:}

The

Independent Variables were accepted in the model (marketing mix, gender, and interaction between gender and marketing mix) explain between (12-39\%) from the total variation of the dependent variable (customer switching behaviour), and the rest percent due to either the random error in the regression model or other Independent Variables excluded from the regression model.

\section{2- F test:}

Since the significant level of $F$ test statistic less than (0.001), it can be revealed that the independent variables were accepted in the model have been affected on the level of CSB.

\section{3- t-test:}

The most significant independent variables accepted in the model are Green product, Green price, Green place, and Green promotion at a significant level at less than (0.001).

There is a significant positive effect of the interaction between gender and marketing mix in terms of Green product, and Green promotion on the construct of customer switching behaviour, at a significant level less than (0.05). This partially validates the second research hypothesis.

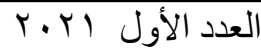

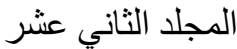


The moderating role of demographic characteristics between green ...

Dr. Sherif Taher Mohammed \& Dr. Reem Mohamed Shafie

Table (6): Multiple Linear Regression Model to determine the effect of the demographic characteristics in terms of age on the relationship between marketing mix and customer switching behaviour

\begin{tabular}{|c|c|c|c|c|c|}
\hline Variable & Coefficient & t-Statistic & Prob. & LLCI & ULCI \\
\hline \multicolumn{6}{|c|}{ 1-the effect of the construct of Green product on customer switching behavior } \\
\hline Constant & 2.6400 & 4.5330 & $0.001 * * *$ & 1.4939 & 3.3321 \\
\hline Green product & .2877 & 2.0771 & $0.0386 *$ & .0151 & .5602 \\
\hline Age & -.4980 & -.7940 & .4278 & -1.7322 & .7362 \\
\hline Green product* Age & .1177 & .7890 & .4308 & -.1759 & .4112 \\
\hline \multicolumn{6}{|c|}{$\mathrm{R}^{2}=16.17 \%$ F-test $=19.28 \mathrm{sig}=0.001 * * * \mathrm{RMSE}=0.3908$} \\
\hline \multicolumn{6}{|c|}{ 2-the effect of the construct of Green price on customer switching behavior } \\
\hline Constant & 2.9465 & 5.8813 & $0.001^{* * *} *$ & 1.9606 & 3.9324 \\
\hline Green price & .2143 & 1.8045 & .0722 & -.0194 & .4479 \\
\hline Age & -.4666 & -.8468 & .3978 & -1.5508 & .6177 \\
\hline Green price * Age & .1170 & .8916 & .3733 & -.1412 & .3752 \\
\hline \multicolumn{6}{|c|}{$\mathrm{R}^{2}=11.38 \%$ F-test 12.84 sig=0.001*** $\mathrm{RMSE}=.4131$} \\
\hline \multicolumn{6}{|c|}{ 3-the effect of the construct of Green place on customer switching behavior } \\
\hline Constant & 2.5795 & 5.6629 & $0.001 * * *$ & 1.6831 & 3.4759 \\
\hline Green place & .3060 & 2.8049 & $.0054 * *$ & .0913 & .5207 \\
\hline Age & -.4144 & -.8259 & .4095 & -1.4019 & .5730 \\
\hline Green place * Age & .0963 & .8019 & .4233 & -.1401 & .3327 \\
\hline \multicolumn{6}{|c|}{$\mathrm{R}^{2}=19.33 \%$ F-test $=23.95$ sig=0.001*** $\mathrm{RMSE}=.3761$} \\
\hline \multicolumn{6}{|c|}{ 4-the effect of the construct of Green promotion on customer switching behavior } \\
\hline Constant & 2.2425 & 4.9426 & $0.001 * * *$ & 1.3496 & 3.1353 \\
\hline Green promotion & .3986 & 3.5576 & $0.001 * * *$ & .1781 & 6191 \\
\hline Age & -1.3881 & -2.7884 & $.0066 * *$ & -2.3859 & -.3904 \\
\hline Green promotion * Age & .3419 & 2.7309 & $.0067 * *$ & .0955 & .5883 \\
\hline
\end{tabular}

According to the Multiple Regression model using ordinary least squares, it can be concluded that:

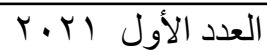


The moderating role of demographic characteristics between green ...

Dr. Sherif Taher Mohammed \& Dr. Reem Mohamed Shafie

\section{1- The coefficient of determination:}

The Independent Variables were accepted in the model (marketing mix, Age, and interaction between Age and marketing mix) explain between (11-39\%) from the total variation of the dependent variable (customer switching behavior), and the rest percent due to either the random error in the regression model or other Independent Variables excluded from the regression model.

\section{2- F test:}

Since the significant level of $F$ test statistic less than (0.001), it can be revealed that the independent variables were accepted in the model have been affected on the level of CSB.

\section{3- t-test:}

The most significant independent variables were accepted in the model are Green product, Green price, Green place, and Green promotion at a significant level at less than (0.001).

There is a significant positive effect of the interaction between Age and marketing mix in terms of Green promotion on the construct of customer switching behaviour, at a significant level less than (0.05). This partially validates the second research hypothesis. 
The moderating role of demographic characteristics between green ...

Dr. Sherif Taher Mohammed \& Dr. Reem Mohamed Shafie

Table (7): Multiple Linear Regression Model to determine the effect of the demographic characteristics in terms of income on the relationship between marketing mix and customer switching behaviour

\begin{tabular}{|c|c|c|c|c|c|}
\hline Variable & Coefficient & t-Statistic & Prob. & LLCI & ULCI \\
\hline \multicolumn{6}{|c|}{ 1-the effect of the construct of Green product on customer switching behavior } \\
\hline Constant & 2.4522 & 6.9504 & $0.001 * * *$ & 1.7579 & 3.1465 \\
\hline Green product & .3310 & 3.9064 & $0.001 * * *$ & .1642 & .4977 \\
\hline Income & -.3857 & -.8641 & .3882 & -1.2641 & .4927 \\
\hline Green product* Income & .0925 & .8672 & .3865 & -.1174 & .3024 \\
\hline \multicolumn{6}{|c|}{$\mathrm{R}^{2}=16.20 \%$ F-test $=19.33$ sig=0.001*** $\mathrm{RMSE}=.3906$} \\
\hline \multicolumn{6}{|c|}{ 2-the effect of the construct of Green price on customer switching behavior } \\
\hline Constant & 2.7108 & 8.2089 & $0.001 * * *$ & 2.0609 & 3.3606 \\
\hline Green price & .2687 & 3.3896 & $0.008 * * *$ & .1127 & .4246 \\
\hline Income & -.2510 & -.5895 & .5560 & -1.0888 & .5869 \\
\hline Green price $*$ Income & .0694 & .6760 & .04996 & -.1327 & .2716 \\
\hline \multicolumn{6}{|c|}{$\mathrm{R}^{2}=11.32 \% \quad$ F-test 12.76 sig=0.001*** $\mathrm{RMSE}=.4134$} \\
\hline \multicolumn{6}{|c|}{ 3-the effect of the construct of Green place on customer switching behavior } \\
\hline Constant & 2.5517 & 8.6648 & $0.001 * * *$ & 1.9722 & 3.1312 \\
\hline Green place & .3108 & 4.3613 & $0.001 * * *$ & .1706 & .4511 \\
\hline Income & -.5401 & -1.3972 & .1634 & -1.3008 & .2206 \\
\hline Green place $*$ Income & .1277 & 1.3755 & .1700 & -.0550 & .3104 \\
\hline \multicolumn{6}{|c|}{$\mathrm{R}^{2}=19.66 \%$ F-test $=24.47 \quad \operatorname{sig}=0.001 * * * \quad \mathrm{RMSE}=.3745$} \\
\hline \multicolumn{6}{|c|}{ 4-the effect of the construct of Green promotion on customer switching behavior } \\
\hline Constant & 1.3857 & 4.3588 & $0.001 * * *$ & .7601 & 2.0113 \\
\hline Green promotion & 6039 & 7.7300 & $0.001 * * *$ & $.4501 /$ & .7576 \\
\hline Income & -.4426 & -1.0655 & .2875 & -1.2599 & .3748 \\
\hline Green promotion $*$ Income & .1184 & 1.1563 & .2485 & -.0831 & .3199 \\
\hline
\end{tabular}

According to the Multiple Regression model using ordinary least squares, it can be concluded that:

\section{1- The coefficient of determination:}

The Independent Variables were accepted in the model (marketing

$$
\text { العدد الأول ابr.r }
$$


The moderating role of demographic characteristics between green ...

Dr. Sherif Taher Mohammed \& Dr. Reem Mohamed Shafie

mix, income, and interaction between income and marketing mix) explain between (11-37\%) from the total variation of the dependent variable (customer switching behavior), and the rest percent due to either the random error in the regression model or other Independent Variables excluded from the regression model.

\section{2- F test:}

Since the significant level of $F$ test statistic less than (0.001), it can be revealed that the independent variables were accepted in the model have been affected on the level of CSB.

\section{3- t-test:}

The most significant independent variables were accepted in the model are Green product, Green price, Green place, and Green promotion at a significant level at less than (0.001).

There is no significant effect of the interaction between income and marketing mix on the construct of customer switching behavior, at a significant level less than (0.05). This partially validates the second research hypothesis.

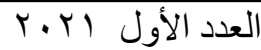

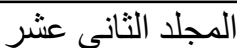


The moderating role of demographic characteristics between green ...

Dr. Sherif Taher Mohammed \& Dr. Reem Mohamed Shafie

Table (8): Multiple Linear Regression Model to determine the effect of the demographic characteristics in terms of education on the relationship between marketing mix and customer switching behavior

\begin{tabular}{|c|c|c|c|c|c|}
\hline Variable & Coefficient & t-Statistic & Prob. & LLCI & ULCI \\
\hline \multicolumn{6}{|c|}{ 1-the effect of the construct of Green product on customer switching behavior } \\
\hline Constant & 1.3970 & 4.0699 & $0.001 * * *$ & .7215 & 2.0725 \\
\hline Green product & .5877 & 7.2966 & $0.001 * * *$ & .4292 & .7462 \\
\hline Education & 1.3518 & 3.0891 & $.0022 * *$ & .4906 & 2.2130 \\
\hline Green product* Education & -.3377 & -3.2484 & $.0013 * *$ & -.5422 & -.1331 \\
\hline \multicolumn{6}{|c|}{$\mathrm{R}^{2}=18.98 \%$ F-test $=23.42$ sig $=0.001 * * *$ RMSE $=.3777$} \\
\hline \multicolumn{6}{|c|}{ 2-the effect of the construct of Green price on customer switching behavior } \\
\hline Constant & 2.6667 & 8.9394 & $0.000^{* * *}$ & 2.0797 & 3.2537 \\
\hline Green price & .2911 & 4.1155 & $0.000^{* * *}$ & .1519 & .4303 \\
\hline Education & -.1682 & -.4011 & .6887 & -.9936 & .6572 \\
\hline Green price $*$ Education & .0276 & .2717 & .7860 & -.1725 & .2278 \\
\hline \multicolumn{6}{|c|}{$\mathrm{R}^{2}=11.32 \%$ F-test $=12.76$ sig $=0.001 * * * \mathrm{RMSE}=.4134$} \\
\hline \multicolumn{6}{|c|}{ 3-the effect of the construct of Green place on customer switching behavior } \\
\hline Constant & 1.9026 & 6.8743 & $0.000 * * *$ & 1.3580 & 2.4473 \\
\hline Green place & .4757 & 7.2421 & $0.000 * * *$ & .3464 & .6049 \\
\hline Education & .6509 & 1.7123 & .0879 & -.0972 & 1.3990 \\
\hline Green place $*$ Education & -.1782 & -1.9607 & $.0508^{*}$ & -.3571 & .0007 \\
\hline \multicolumn{6}{|c|}{$\mathrm{R}^{2}=20.52 \%$ F-test $=25.81 \quad$ sig $=0.001 * * * \quad \mathrm{RMSE}=.3705$} \\
\hline \multicolumn{6}{|c|}{ 4-the effect of the construct of Green promotion on customer switching behavior } \\
\hline Constant & 1.0129 & 3.5043 & $0.005^{* * *}$ & .4441 & 1.5817 \\
\hline Green promotion & .7031 & 10.0179 & $0.000 * * *$ & .5650 & .8412 \\
\hline Education & .2564 & .6216 & .5347 & -.5554 & 1.0682 \\
\hline Green promotion * Education & -.0679 & -.6649 & .5066 & -.2687 & .1330 \\
\hline
\end{tabular}

According to the Multiple Regression model using ordinary least squares, it can be concluded that:

\section{1- The coefficient of determination:}

The Independent Variables were accepted in the model (marketing mix, education, and an interaction between education and marketing

$$
\text { العدد الأول اYr.r }
$$


The moderating role of demographic characteristics between green ...

Dr. Sherif Taher Mohammed \& Dr. Reem Mohamed Shafie

mix) explain between (11-37\%) from the total variation of the dependent variable (customer switching behaviour), and the rest percent due to either the random error in the regression model or other Independent Variables excluded from the regression model.

2- F test:

Since the significant level of F test statistic less than (0.001), it can be revealed that the independent variables were accepted in the model have been affected on the level of CSB.

\section{3- t-test:}

The most significant independent variables were accepted in the model are Green product, Green price, Green place, and Green promotion at a significant level at less than (0.001).

There is a significant positive effect of the interaction between education and marketing mix in terms of Green product and Green place on the construct of customer switching behavior, at a significant level less than (0.05). This partially validates the second research hypothesis.

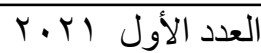

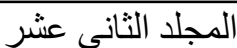


The moderating role of demographic characteristics between green ...

Dr. Sherif Taher Mohammed \& Dr. Reem Mohamed Shafie

Table (8): Multiple Linear Regression Model to determine the effect of the demographic characteristics in terms of marital status on the relationship between marketing mix and customer switching behavior

\begin{tabular}{|c|c|c|c|c|c|}
\hline Variable & Coefficient & t-Statistic & Prob. & LLCI & ULCI \\
\hline \multicolumn{6}{|c|}{ 1-the effect of the construct of Green product on customer switching behavior } \\
\hline Constant & 3.0463 & 5.1751 & $0.000 * * *$ & 1.8879 & 4.2048 \\
\hline Green product & .1786 & 1.2953 & .1962 & -.0927 & .4499 \\
\hline Marital status & -.9741 & -1.5403 & .1245 & -2.2186 & .2704 \\
\hline Green product* Marital status & .2484 & 1.6722 & $.0955^{*}$ & -.0439 & .5407 \\
\hline \multicolumn{6}{|c|}{$\mathrm{R}^{2}=16.98 \%$ F-test $=20.45$ sig $=0.001 * * * \mathrm{RMSE}=.3870$} \\
\hline \multicolumn{6}{|c|}{ 2-the effect of the construct of Green price on customer switching behavior } \\
\hline Constant & 2.9786 & 6.2074 & $0.000^{* * * *}$ & 2.0343 & 3.9229 \\
\hline Green price & .1981 & 1.7397 & $.0829^{*}$ & -.0260 & .4223 \\
\hline Marital status & -.5220 & -.9801 & .3278 & -1.5700 & .5260 \\
\hline Green price $*$ Marital status & .1416 & 1.1148 & .2658 & -.1084 & .3916 \\
\hline \multicolumn{6}{|c|}{$\mathrm{R}^{2}=11.66 \%$ F-test 13.19 sig=0.001*** RMSE $=.4118$} \\
\hline \multicolumn{6}{|c|}{ 3-the effect of the construct of Green place on customer switching behavior } \\
\hline Constant & 2.5431 & 5.8084 & $0.000^{* * * *}$ & 1.6815 & 3.4047 \\
\hline Green place & .3027 & 2.9176 & $.0038^{* *}$ & .0985 & .5068 \\
\hline Marital status & -.3798 & -.7807 & .4356 & -1.3373 & .5776 \\
\hline Green place * Marital status & .1040 & .9000 & .3688 & -.1234 & .3314 \\
\hline \multicolumn{6}{|c|}{$\mathrm{R}^{2}=19.46 \%$ F-test $=24.16 \quad$ sig $=0.001 * * * \quad$ RMSE $=.3754$} \\
\hline \multicolumn{6}{|c|}{ 4-the effect of the construct of Green promotion on customer switching behavior } \\
\hline Constant & 1.6928 & 3.8046 & $0.000^{* * *}$ & .8172 & 2.5684 \\
\hline Green promotion & .5236 & 4.7921 & $0.000 * * *$ & .3086 & .7386 \\
\hline Marital status & -.7154 & -1.4288 & .1541 & -1.7008 & .2699 \\
\hline $\begin{array}{c}\text { Green promotion * Marital } \\
\text { status }\end{array}$ & .1902 & 1.5443 & .1236 & -.0522 & .4325 \\
\hline
\end{tabular}

According to the Multiple Regression model using ordinary least squares, it can be concluded that:

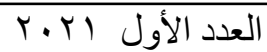


The moderating role of demographic characteristics between green ...

Dr. Sherif Taher Mohammed \& Dr. Reem Mohamed Shafie

\section{1- The coefficient of determination:}

The Independent Variables were accepted in the model (marketing mix, Marital status, and interaction between Marital status and marketing mix) explain between (12-38\%) from the total variation of the dependent variable (customer switching behavior), and the rest percent due to either the random error in the regression model or other Independent Variables excluded from the regression model.

\section{F test:}

Since the significant level of $F$ test statistic less than (0.001), it can be revealed that the independent variables were accepted in the model have been affected on the level of CSB.

\section{2- t-test:}

The most significant independent variables were accepted in the model are Green product, Green price, Green place, and Green promotion at a significant level at less than (0.001).

There is a significant positive effect of the interaction between Marital status and marketing mix in terms of Green product on the construct of customer switching behavior, at a significant level less than (0.05). This partially validates the second research hypothesis.

\section{1- Conclusion, Discussion, and Recommendations}

The current study descriptive results show that $(40,3 \%)$ of respondents aware of environmental issues and eco-friendly products and the rest (59.7\%) do not know. Furthermore, the majority of respondents were male $(50.2 \%)$ and the rest $(49.8 \%)$ 
The moderating role of demographic characteristics between green ...

Dr. Sherif Taher Mohammed \& Dr. Reem Mohamed Shafie

were female. (80.4\%) of the respondents were fall into (20 to 30 years) age group. Besides, it is clear from the descriptive results that most of the respondents $(53 \%)$ were well educated as they had a graduate educational level. The income levels of the major respondents (67.3\%) were (5 to 10 thousand) LE/Month. Additionally, most respondents were single with a percentage $(55 \%)$.

In the present study, several limitations are needed to be considered. Firstly, the analysis concentrated only on the green marketing mix and the consumer switching behaviour. Secondly, this study only emphasizes on four aspects of the green marketing mix (green price, green product, green promotion, and green distribution). Subsequent research is needed to consider more different aspects, for example, 7P's. The findings steered us to draw conclusions about the relationship between green marketing mix with the customer switching behaviour by using customers' demographic characteristics as moderator variables and make recommendations for future research. Therefore, this research offers significant realistic and theoretical ramifications that marketers are required to work to promote a favourable attitude toward eco-friendly vehicles. The need for green vehicles in Egypt can be increased by strong collaboration between the government and all main players in the automotive industry. Consequently, the achievement of environmental growth and the Green Mission of the Egyptian Government may be accomplished 
The moderating role of demographic characteristics between green ...

Dr. Sherif Taher Mohammed \& Dr. Reem Mohamed Shafie

in Egypt in the coming days.

The empirical results of the study found that the green marketing mix (green product, green price, green place, and green promotion) was found to have a significant relationship with customer switching behaviour (H1 was accepted) this is consistent with (Mahmoud, 2018; Siddique \&Hossain, 2018). From the above analysis, it can be concluded that the current research's results regarding the moderating effects of customers' demographic characteristics are a useful confirmation, in an ecofriendly automobile industry context, gender as a modified variable affects the switching behaviour of the customers, where males became the most respondents want to use eco-friendly vehicles, compared to females and the current study found that there is a positive relationship between Egyptian consumers educational level and consumer switching behaviour toward ecofriendly vehicles.

There is a significant positive effect of the interaction between gender and marketing mix in terms of green product, and green promotion on the construct of customer switching behaviour, at a significant level less than (0.05). In addition to there is a significant positive effect of the interaction between Age and marketing mix in terms of green promotion on the construct of customer switching behaviour, at a significant level less than (0.05). Meanwhile, there is no significant effect of the interaction between income and marketing mix on the construct of customer switching behaviour, at a significant level less

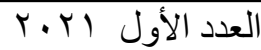

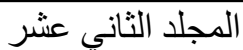


The moderating role of demographic characteristics between green ...

Dr. Sherif Taher Mohammed \& Dr. Reem Mohamed Shafie

than (0.05). on the other hand, there is a significant positive effect of the interaction between educational level and marketing mix in terms of green product and green place on the construct of customer switching behaviour, at a significant level less than (0.05). Finally, there is a significant positive effect of the interaction between marital status and marketing mix in terms of green product on the construct of customer switching behaviour, at a significant level less than (0.05). This partially validates the second research hypothesis ( $\mathrm{H} 2$ was partially accepted).

Briefly, the findings suggest that consumer perception of ecofriendly automobile products is generally high and positive they also suggest that green marketing mix factors are a worthwhile focus point for green marketers, as they do elicit a significant behaviour change. As for the demographic characteristics factors marketers should consider when they generate marketing mix strategies. Also, green automobile marketers can use celebrities and social influencers to communicate a greener lifestyle which will expand the customer base of green shoppers for green cars. Besides, since the context of the current research is the purchasing of automotive goods, more research could be performed in other industrial settings, as health supplements or food and drink products, including the comparison of behavioural patterns and potential differences. Also, it is proposed that other factors could be used as moderators in the model, like environmental awareness, idealistic and hedonistic principles. This is because diverse consumer

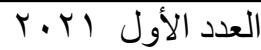

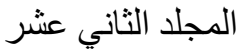


The moderating role of demographic characteristics between green ...

Dr. Sherif Taher Mohammed \& Dr. Reem Mohamed Shafie

backgrounds will offer different responses and deeper insights for decision-makers, advertisers, and practitioners to search green conduct from different points of view. Moreover, targeted generations should be expanded to other age ranges, since different group demographics have different green buying habits. Therefore, the findings reported will be more detailed.

For those involved in this respect, some of the guidelines implemented are proposed:

$\checkmark$ Enhancing the green products' consistency and seeking to improve their durability.

$\checkmark$ Employing facilities and the latest technology for acceptable designing, manufacturing, pricing, promotion, and delivery.

$\checkmark$ Considering the environment and creating an environmental marketing department, planning the framework, mobilizing sufficient resources and opportunities by companies.

$\checkmark$ Environmentally sustainable car manufactures must follow improved strategies for battery operation, like battery sharing, when at the same time improving the production of battery technology, as customers claim that the price and lifespan of batteries would influence their purchasing intentions. Manufacturers should incorporate the idea of an automotive recycling economy, involving automotive 
The moderating role of demographic characteristics between green ...

Dr. Sherif Taher Mohammed \& Dr. Reem Mohamed Shafie

retrieval and battery-powered recycling, aiming at minimizing the cost of batteries by reusing scrap cars and their components, retrieval as well as waste recycling to encourage the safe and balanced growth of the automotive industry.

$\checkmark$ As customers expect that the charging batteries' number for electric cars would influence their buying behaviour, the government is proposed to implement a pilot model of battery charging as a prototype in major cities, and then draw investment from the related producers by incentives to ease the challenge of electric vehicle charging.

Eventually, it is proposed that the green buying advice could be delivered more successfully by growing ecological concerns within Egyptian customers. To boost the degree of environmental consciousness or environmental issues of Egyptian customers, various environmental initiatives, like the "Prepare for Green" campaign, should be sponsored by lawmakers, corporate groups, or other Nongovernmental organizations. that would increase the readiness of Egyptian customers to buy green cars.

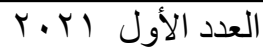

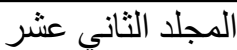


The moderating role of demographic characteristics between green ...

Dr. Sherif Taher Mohammed \& Dr. Reem Mohamed Shafie

\section{References :}

1. Aarikka-Stenroos, L., \& Jaakkola, E. (2012). Value co-creation in knowledge intensive business services:

2. Achola, G. O. and Were, S. (2018), "Influence of Marketing Strategies on Performance of Fast-Moving Consumer Goods Companies in Nairobi in Kenya", Journal of Marketing and Communication, Vol. 2 No.2, pp. 31-42.

3. Agnes Viani Parlan, Andriani Kusumawatim M. Kholid Mawardi, Jurnal Administrasi Bisnis (JAB)|Vol. 39 No.1 Oktober 2016

4. Aman, A. H. L., Harun, A., \& Hussein, Z. (2012). The influence of environmental knowledge and concern on green purchase intention the role of attitude as a mediating variable. British Journal of Art and Social Sciences, 7 (2), 145 - 167.

5. Ankit and Mayur (2013). Green Marketing: Impact of Green Advertising on Consumer Purchase Intention. Advances Manage, 6(9), 14-17.

6. Ansar N (2013). Impact of green marketing on consumer purchase intention. Mediterranean Journal of Social Sciences, 4(11): 650-655.

7. Awan U (2011). Green marketing: Marketing strategies for the Swedish energy companies. International Journal of Industrial Marketing, 1(2): 1-19.

8. Awan, U. (2011). Green marketing: Marketing strategies for the Swedish energy companies. International Journal of Industrial Marketing, 1(2), 1-19.

9. Balaji, M. S. (2015). Investing in customer loyalty: The moderating role of relational characteristics. Service Business, 9(1), 17-40.

10. Beyzavi, M., \& Lotfizadeh, F. (2014). Analyzing the choice behavior based on the theory of consumption values for green products in Iran.

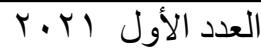

المجلد الثاني عشر 
The moderating role of demographic characteristics between green ...

Dr. Sherif Taher Mohammed \& Dr. Reem Mohamed Shafie

Kuwait Chapter of Arabian Journal of Business and Management Review, 3(12a), 124-134.

11. Chen, T. B., \& Chai, L. T. (2010). Attitude towards the environment and green products: consumers' perspective. Management Science and Engineering, 4 (2), 27 - 39.

12. Dahl, U., \& Persson, S. (2008). Purchasing of environmental friendly computers, Bachelor Thesis within Business Administration, Jonkoping International Business School.

13. Devi Juwaheer T, Pudaruth S, and Monique Emmanuelle Noyaux M (2012). Analysing the impact of green marketing strategies on consumer purchasing patterns in Mauritius. World Journal of Entrepreneurship, Management and Sustainable Development, 8(1): 36-59.

14. Edvardsson, Bo, Anders Gustafsson, and Inger Roos (2002a), "Comparing Switching Patterns in Competitive and Non-Competitive Markets- Customer Preferences and Behavior in Five Service Industries," 11th Annual American Marketing Association Frontiers in Services Conference, June 27-29, Maastricht, the Netherlands.

15. Eric K (2007). Green marketing practises by kenya petroleum refineries: A study of the perception of the management of oil marketing companies in kenya. Ph.D. Dissertation, University Of Nairobi, Kenya.

16. Fan and Zeng (2011). Implementation of green marketing strategy in China: A study of the green food industry. M.Sc. Thesis, University of GAVLE, China.

17. Fan $H$ and Zeng L (2011). Implementation of green marketing strategy in China: A study of the green food industry. M.Sc. Thesis, University of GAVLE, China.

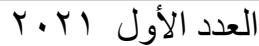

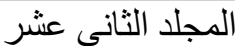


The moderating role of demographic characteristics between green ...

Dr. Sherif Taher Mohammed \& Dr. Reem Mohamed Shafie

18. Fornell, C.; Larcker, D. (1981). Evaluating structural equation models with unobservable variables and measurement error. Journal of Marketing Research, Vol.18, Iss.3, PP.39-50.

19. Gan C, Wee HY, Ozanne L, and Kao TH (2008). Consumers' purchasing behavior towards green products in New Zealand. Innovative Marketing, 4(1): 93-102.

20. Gazzola, P.; Del Campo, A.G.; Onyango, V. Going green vs going smart for sustainable development: Quo vadis? J. Clean. Prod. 2019, 214, 881-892.

21. Hair, F.J.; Sarstedt, M.; Hopkins, L.; Kuppelwieser, G.V. (2014). Partial least squares structural equation modeling (PLS-SEM). European Business Review, Vol.26, Iss.2, PP.106-121.

22. Han, H., Hsu L., Lee J., \& Sheu Ch. (2011). Are lodging customers ready to go green? An examination of attitudes, demographics, and ecofriendly intentions. International Journal of Hospitality Management, 30, 345-355.

23. Hashem TN and Al-Rifai NA (2011). The influence of applying green marketing mix by chemical industries companies in three Arab States in West Asia on consumer's mental image. International Journal of Business and Social Science, 2(3): 92-101.

24. Henseler, J., Ringle, C. M., \& Sarstedt, M. (2015). A New Criterion for Assessing Discriminant Validity in Variance-Based Structural Equation Modeling. Journal of the Academy of Marketing Science, 43(1), 115-135.

25. Hossain, A. and Khan, M.Y. (2018), "Green Marketing Mix Effect on Consumers Buying Decisions in Bangladesh", Marketing and Management of Innovations, Vol. 10 No. 4, pp. 298-306.

26. Joshi, N., \& Rao, P. S. (2013). "Environment friendly car: Challenges ahead in India". Global Journal of Management and Business Research Interdisciplinary, 13(4), 11-19.

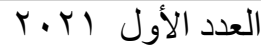

المجلد الثاني عشر 
The moderating role of demographic characteristics between green ...

Dr. Sherif Taher Mohammed \& Dr. Reem Mohamed Shafie

27. Karurkar, S., Unnikrishnan, S., \& Panda, S. S. (2018). Study of Environmental Sustainability and Green Manufacturing Practices in the Indian Automobile Industry. Retrieved from https://papers.ssrn.com/sol3/papers.cfm?abstract_id=3283358

28. Kawitkar, S. S. (2013). Impact of eco-friendly products on consumer behavior. International Indexed \& Refereed Research Journal, 40, $42-44$.

29. Keaveney, S. M., (1995) Customer Switching Behavior in Service Industries: An Exploratory Study. Journal of Marketing, 59, 71-82.

30. Kline, T. J. B., Sulksy, L. M., \& Rever-Moriyama, S. D. (2011). Common method variance and specification errors:A practical approach to detection. The Journal of Psychology, 134(4), 401-421.

31. Kotler, P. (2012). Marketing Management, millennium edition: Custom Edition for University of Phoenix.

32. Kotler, P., and Armstrong, G. (2009). Principles of Marketing. Prentice Hall, New Jersey.

33. Kumar P and Ghodeswar BM (2015). Factors affecting consumers' green product purchase decisions. Marketing Intelligence and Planning, 33(3): 330-347.

34. Kumar, P. (2015). Green marketing products in India. DAV Academic Review, 1(1), 1-12.

35. Lam SY and Mukherjee A (2005). The effects of merchandise coordination and juxtaposition on consumers' product evaluation and purchase intention in store-based retailing. Journal of Retailing, 81(3): 231-250.

36. Laroche M, Bergeron J, and Barbaro-Forleo G (2001). Targeting consumers who are willing to pay more for environmentally friendly products. Journal of consumer marketing, 18(6): 503-520.

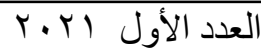

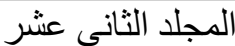


The moderating role of demographic characteristics between green ...

Dr. Sherif Taher Mohammed \& Dr. Reem Mohamed Shafie

37. M.D., P., \& Akhil, A. (2017). Green Marketing to Meet Consumer Demands and Sustainable Development-Challenges and Opportunities. Retrieved from https://papers.ssrn.com/sol3/papers.cfm?abstract_id=2980024

38. Mahmoud, T. (2018). the impact of green marketing mix on purchase intention. International Journal of Advanced And Applied Sciences, 5(2), 127-135.

39. Marchi, B., \& Zanoni, S. (2017). Supply Chain Management for Improved Energy Efficiency: Review And Opportunities. Energies, 10(10), 1618. https://doi.org/10.14299/ijser.2017.09.006

40. Ottman, Jacquelyn A., Stafford, E.R.L. \& Hartman, C. (2006). Green Marketing Myopia, Heldref Publications, 48, 5.

41. Paul J and Rana J (2012). Consumer behavior and purchase intention for organic food. Journal of consumer Marketing, 29(6): 412-422.

42. Phau,I., \& .Ong,D.,(2007). An investigation of the effects of environmental claims.

43. Rahman, M. M. (2013). Green product: A study on young \& native Swedish consumers' purchase intention of green products. Master's Thesis, 1-47.

44. Razak, M. I. M., Ahmad, H. I., Bujang, I., Talib, A. H., \& Ibrahim, Z. (2013). Economics of air pollution in Malaysia. International Journal of Humanities and Social Science, 3(13), 173-177.

45. Ritter, M., Borchardt, M., Vaccaro, L., Pereira, M., \& Almeida, F. (2015). Motivations for promoting the consumption of green products in an emerging country: 104 Journal of Management Sciences Exploring attitudes of Brazilian consumers. Journal of Cleaner Production, 106, 507-520. https://doi.org/10.1016/j.jclepro.2014.11.066 46. Schiffman, L.G., Kanuk, L.L. and Hansen, H. (2008), Consumer Behaviour: A European Outlook, p4.England, Prentice Hall. 
The moderating role of demographic characteristics between green ...

Dr. Sherif Taher Mohammed \& Dr. Reem Mohamed Shafie

47. Shil P (2012). Evolution and future of environmental marketing. Asia Pacific Journal Of Marketing and Management Review, 1(3): 74- 81.

48. Shirsavar and Fashkhamy (2013). Green marketing: A new paradigm to gain competitive advantage in contemporary business.Trends in Advanced Science and Engineering, 7(1), 12-18.

49. Siddique, Z. R. and Hossain, A., (2018). Sources of Consumers Awareness toward Green Products and Its Impact on Purchasing Decision in Bangladesh. Journal of Sustainable Development, 11(3), 9-22.

50. Singh G (2013). Green: the new colour of marketing in India. ASCI Journal of Management, 42(2): 52-72.

51. Singhal, N., \& Effiong, J. (2016). Impact of Green Business Model on Sustainability Management of Indian Corporate Organisations: Review of Issues and Opportunities for Business Growth. Retrieved from https://papers.ssrn.com/sol3/papers.cfm?abstract_id=2819305

52. Sivesan, S., Achchuthan, S. and Umanakenan, K., (2013). Green Marketing Practices and Customer Satisfaction: A Special Reference to Leather Goods. Global Journal of Management and Business Research Accounting and Auditing, 13(3), 50-59.

53. Solvalier I (2010). Green marketing strategies case study about ICA group AB. M.Sc. Thesis, Karlstad University, Karlstad, Sweden.

54. Soonthonsmai, V. (2007). Environmental Or Green Marketing As Global Global Competitive Fdge: Concept, Synthesis, And Implication, EABR (Business) \&ETLC (Teaching) Conference Proceedings, Venice, Italy.

55. Tavakol, M.; Dennick, R. (2011). Making sense of Cronbach's alpha. International journal of medical education, Vol.2, PP.53-55.

56. Teo, T., Lee, C. B., \& Chai, C. S. (2008). Understanding pre-service teachers' computer attitudes: Applying and extending the Technology 
The moderating role of demographic characteristics between green ...

Dr. Sherif Taher Mohammed \& Dr. Reem Mohamed Shafie

Acceptance Model (TAM). Journal of Computer Assisted Learning, 24(2), 128-143.

57. Tsarenko, Y., Ferraro, C., Sands, S., \& McLeod, C. (2013). Environmentally conscious consumption: the role of retailers and peers as external influences. Journal of Retailing and Consumer Services, 20 (3), $302-310$.

58. Wanninayake WMCB and Randiwela P (2008). Consumer attractiveness towards green products of FMCG sector: An empirical study. In the Oxford Business and Economics Conference, Oxford University, Oxford, UK.

59. Wong,V.Turner, W. \&Stoneman .P.(2009).MarketingStrategies and Market Propects for Environmentally Friendly . Consumer Product BritishJournal.

60. Yazdanifard R and Mercy IE (2011). The impact of green marketing on customer satisfaction and environmental safety. In the 2011 International Conference on Computer Communication and Management, IACSIT Press, Singapore, 5: 637-641. 